\title{
OCCURENCE OF MICROPLASTICS IN WATER, SEDIMENT AND MILKFISH (Chanos chanos) IN CITARUM RIVER DOWNSTREAM (CASE STUDY: MUARA GEMBONG)
}

\author{
Achmad Agustian Fareza and Emenda Sembiring* \\ Environmental Engineering Study Program, Faculty of Civil and Environmental Engineering, Institut Teknologi Bandung. \\ J1. Ganesha No. 10, Bandung, Indonesia. 40135.
}

\begin{abstract}
Microplastics in aquatic environment can possibly enter into the aquatic organism, so this study aims to identify the microplastic concentrations in water, sediment, and milkfish. The samples are taken in downstream Citarum river at Muara Gembong. Water samples were taken using a manta trawl pulled by a boat while sediment and milkfish samples were taken using the grab sampling method. Organic removal and cleaning was conducted by using the Fenton Oxidation method which use $\mathrm{Fe}$ and $\mathrm{H}_{2} \mathrm{O}_{2}$. The average of microplastic concentrations in river water, seawater ponds, mixed water, and seawater consecutively are $0.0574 \pm 0.025$ particles $/ \mathrm{m}^{3}, 3.000 \pm 2.645$ particles $/ L, 0.666 \pm 0.577$ particles $/ L$ and $1.333 \pm 1.155$ particles/L. The average of microplastic concentrations in sediment sea water pond, sediment mixed water pond and sea sediment samples consecutively are $3.666 \pm 0.577$ particles $/ 20 \mathrm{~g}, 2.667 \pm 1.527$ particles $/ 20 \mathrm{~g}$, $2.333 \pm 0.577$ particles $/ 20 \mathrm{~g}$ and $0.667 \pm 1.154$ particle $/ 20 \mathrm{~g}$. The average of microplastic concentrations in the gut and gills of milkfish in sea ponds and mixed ponds consecutively are $2.333 \pm 2.266$ particles/fish and $2.222 \pm 3.768$ particles/fish. The average of microplastic concentrations in milkfish tissues in the sea and mixed water ponds are $1.333 \pm 1.000$ particles/fish and $1.111 \pm 1.167$ particles/fish.
\end{abstract}

\section{Introduction}

Plastic production has increased since 1950 [1]. In 2012, global production of waste had reached 3,4 million tons and half of it is a non-degradable waste and this figure is expected to double by 2025 [2]. The improper plastic disposals eventualy will be fragmented and have led to an increase in tiny plastic particles including microplastic which polluting the environment $[3,4]$. Microplastic is plastic which size $<5 \mathrm{~mm}$. [3,4]. Microplastics have been observed and founded in marine [5], freshwater [6,7], and terrestrial [8].

Microplastic in the environment can possibly consumed by the organism, across trophic levels through zooplankton $[9,10]$, annelids $[11,12]$, echinoderms $[13,14]$, bivalves $[15,16]$, fish [17-19], turtles [20] and birds [21]. The effect of microplastics intake by fish was been also observed by several authors. Microplastic (polyethylene) has been reported to reduce significantly acethyleholinesterase (AChE) in juvenils [22]. In addition, $100 \%$ fish mortality was observed after $96 \mathrm{~h}$ polyethylene [22].

Citarum is the biggest river in West Java on which occupied an area $6,614 \mathrm{~km}^{2}$. There are 2,822 industries and 18.64 million residents who reside along the river. Citarum River is one of the dirtiest and most polluted rivers in the world and has the losses for the people who still utilize the water of Citarum River [23]. The abundance of microplastics often associated with population density and the resident's activity [24]. This research aims to identify of microplastics in water, sediment, and milkfish.

\section{Methodology}

\subsection{Sampling location}

This study was conducted on Citarum river downstream, especially at Muara Gembong, Bekasi District. The sampling location was shown at Fig.1

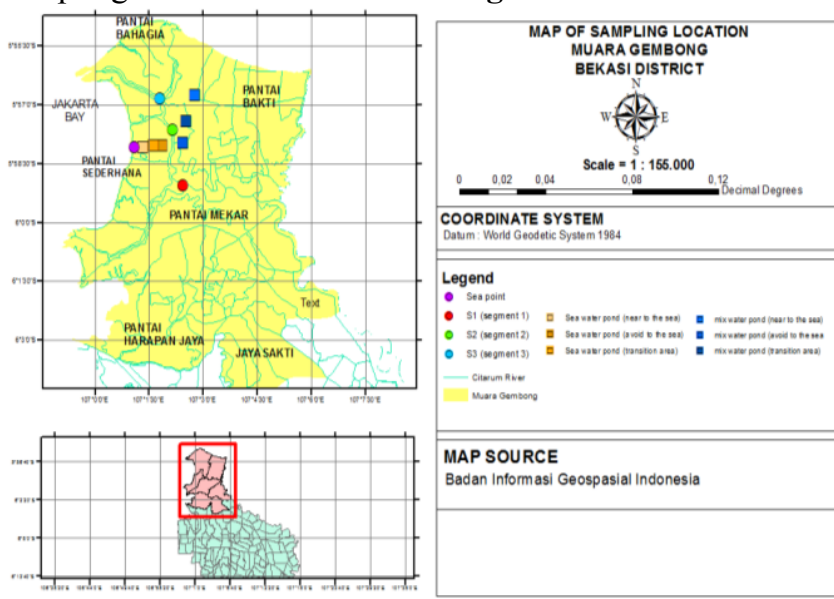

Fig.1 Sampling location

\footnotetext{
*Corresponding autrhor: emenda@ftsl.itb.ac.id; endasembiring@yahoo.com
} 


\subsection{Sampling methods}

The determine of sampling point on the river and the milkfish pond based on purposive sampling, based on the sampling location and the water used for the pond. The water sample at the river and milkfish pond taken by manta trawl and grab sampling while sediment samples taken by Eckmann Grab [25]. Volume reduce water takes only one sample at a time. The sampling period was in March 2019, during wet season.

\subsection{Microplastics separation}

Separated water sample according to the mesh that used at manta trawl $(125 \mu \mathrm{m})$. The sample that held with a mesh will dry at $60^{\circ} \mathrm{C}$ and then the destruction are used Fenton Oxidation method using $\mathrm{H}_{2} \mathrm{O}_{2}$ and $\mathrm{Fe}$ to clean the organic materials with $75^{\circ} \mathrm{C}[25,26]$. Particles that suspected as microplastics were picked and put to the petri disk [26]. After destruction process, sediment sample will be separated by density used $\mathrm{ZnCl} 1,5 \mathrm{~g} / \mathrm{cm}^{3}$ where the plastic that has a density less than $1,5 \mathrm{~g} / \mathrm{cm}^{3}$ will be lifted and picked to the petri disk [26]. Samples of milkfish were taken using purposive sampling method [26]. Milkfish is a common aquaculture in Muara Gembong. The amount of fish sample for each pond were three fishes. Milkfish samples were measured length and weight to determine the profile of milkfish samples [27]. The part of milkfish that taken was gut, gill, and tissue because the microplastic is more accumulated in the gut and gill [27]. The milkfish's tissue was taken to determine the microplastic concentration in milkfish's tissues. The milkfish were weighed and destroyed using the Fenton Oxidation method which has been modified with the weight ratio of the milkfish and volume of $\mathrm{H}_{2} \mathrm{O}_{2} 30 \%$ (w/v) was 1:5 $[27,28]$. Next, the samples were filtered using Whatmann GF/C by vacuum pump after that, the samples that suspected as microplastic were picked up for analysis using FT-IR [29].

\subsection{Microplastics visualization}

Visualization with a microscope was carried out to determine the shape and size of microplastic using ImageJ software [30]. The type of plastic polymer determined visualization using FT-IR. The wavelength range used in FT-IR between $\left(4000-550 \mathrm{~cm}^{-1}\right)$ where the results of the polymer spectrum will be matched with the polymer spectrum standard [29].

\section{Result and discussion}

\subsection{Microplastic concentration at a water sample}

Based on the result, it found that the highest microplastic concentration in river at water sample was in segment 1 , around $0.08613 \pm 0.004$ particles $/ \mathrm{m}^{3}$. The highestmicroplastic concentration in milkfish pond was in seawater pond water with $3.000 \pm 2.645$ particles/liter. The result could be seen in Table 1.

Table 1. Microplastics concentration at water samples

\begin{tabular}{|c|c|c|c|}
\hline \multicolumn{2}{|c|}{ Location } & \multicolumn{2}{|c|}{$\begin{array}{l}\text { Microplastic } \\
\text { concentration }\end{array}$} \\
\hline \multirow[t]{3}{*}{ The river } & Segment 1 & $\begin{array}{l}0.08613 \\
\text { particles } / \mathrm{m}^{3}\end{array}$ & 0.004 \\
\hline & Segment 2 & $\begin{array}{l}0.04805 \stackrel{ \pm}{ \pm} \\
\text { particles } / \mathrm{m}^{3}\end{array}$ & 0.000 \\
\hline & Segment 3 & $\begin{array}{l}0.03810 \pm \\
\text { particles } / \mathrm{m}^{3}\end{array}$ & 0.0031 \\
\hline \multirow[t]{2}{*}{ Milkfish pond } & Sea water & $\begin{array}{l}3.000 \pm \\
\text { particles/litr }\end{array}$ & 2.645 \\
\hline & Mixing water & $\begin{array}{l}0.666 \quad \pm \\
\text { particles/litr }\end{array}$ & 0.577 \\
\hline The sea & - & $\begin{array}{l}1.333 \pm \\
\text { particles/litr }\end{array}$ & .155 \\
\hline
\end{tabular}

Based on characterization of microplastics, the most shape, color and size of microplastic, at water samples from Citarum River were black fragments with the size range $1000-5000 \mu \mathrm{m}$, in milkfish pond were black film with the size range $500-1000 \mu \mathrm{m}$ and the sea were blue and red fragment with the size range $500-1000 \mu \mathrm{m}$. The result can be seen in Fig` 3.

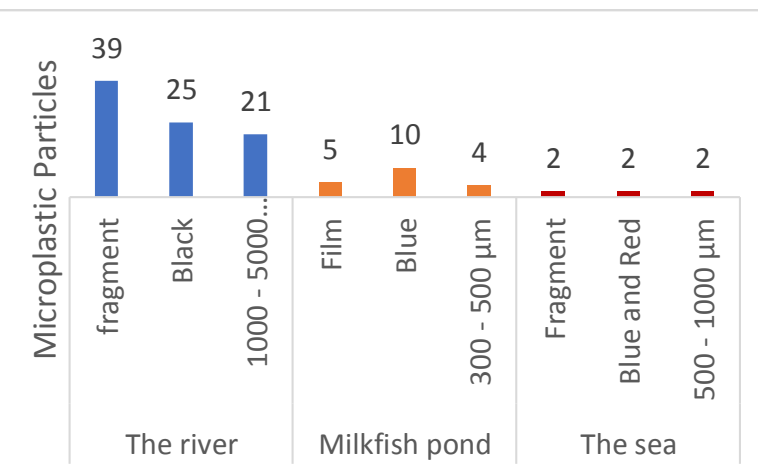

Fig 3. The amount of microplastic concentration based on shape, color and the size at water samples

\subsection{Microplastic concentration at the sediment}

The amount of microplastic concentrations in sediment samples presented in Table 2. It appears that the concentration of microplastic in sediment samples downstream of Citarum River taken as many as 20 grams most found in Segment 1 (avoid to the sea) with $4.00 \pm 0.316$ particles/20gram. The highest microplastic concentration in sediment samples at milkfish ponds was in the pond that used seawater with $2.667 \pm 1.527$ particles/20 gram and the highest microplastic concentration in sediment at the sea was $0.667 \pm 1.154$ partikel/20gr. 
Table 2. Microplastic concentration in sediment samples

\begin{tabular}{|c|c|c|c|}
\hline \multicolumn{2}{|c|}{ Location } & \multicolumn{2}{|c|}{$\begin{array}{l}\text { Microplastics } \\
\text { concentration }\end{array}$} \\
\hline \multirow[t]{3}{*}{ The river } & Segment 1 & $\begin{array}{l}4 \quad \pm \\
\text { partikel/20gr }\end{array}$ & 0.707 \\
\hline & Segment 2 & $\begin{array}{l}3.4 \quad \pm \\
\text { partikel/20gr }\end{array}$ & 0.894 \\
\hline & Segment 3 & $\begin{array}{l}2.6 \quad \pm \\
\text { partikel/20gr }\end{array}$ & 0.548 \\
\hline \multirow[t]{2}{*}{$\begin{array}{l}\text { Milkfish } \\
\text { pond }\end{array}$} & Seawater & $\begin{array}{l}2.667 \pm \\
\text { partikel/20gr }\end{array}$ & 1.527 \\
\hline & Mixing water & $\begin{array}{l}2.333 \pm \\
\text { partikel/20gr }\end{array}$ & 0.577 \\
\hline The sea & - & $\begin{array}{l}0.667 \pm \\
\text { partikel/20gr }\end{array}$ & 1.154 \\
\hline
\end{tabular}

Based on characterization of microplastic, The most shape, color and size in sediment samples were black fibers with the size range $1000-5000 \mu \mathrm{m}$, whereas in milkfish pond were blue fragments with the size range $1000-5000 \mu \mathrm{m}$ and the sea were blue fragment with the size range $500-1000 \mu \mathrm{m}$. The result can be seen in Fig 4.

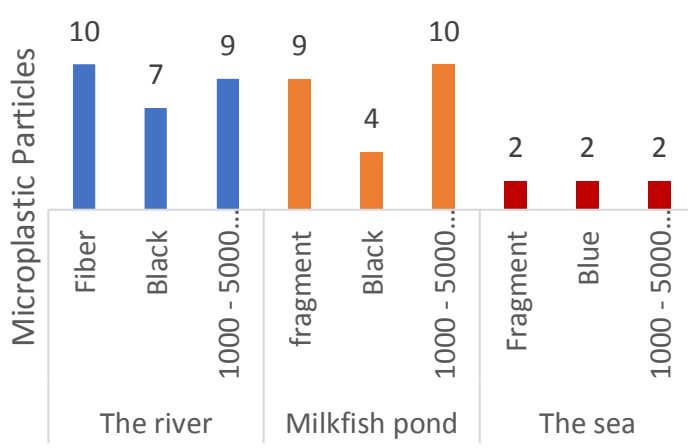

Fig 4. The amount of microplastic concentration based on shape, color and the size at sediment samples

\subsection{Microplastic concentration at milkfish}

The average of microplastic concentrations in milkfish samples is presented in Table 3. Based on Table 3. the highest microplastic concentrations in the fish both from seawater and mixed water ponds were gut and gills. The highest microplastic concentration in fish's tissue was in seawater pond.

Table 3. Microplastic concentration at milkfish samples

\begin{tabular}{|c|l|l|}
\hline \multicolumn{2}{|c|}{ Location } & $\begin{array}{l}\text { Microplastic } \\
\text { concentration }\end{array}$ \\
\hline \multirow{4}{*}{ Seawater pond } & $\begin{array}{l}\text { Gut and } \\
\text { gill }\end{array}$ & $\begin{array}{l}2.333 \pm 2.266 \\
\text { particles/fish }\end{array}$ \\
\cline { 2 - 3 } & tissue & $\begin{array}{l}1.333 \pm 1.000 \\
\text { particles/fish }\end{array}$ \\
\hline \multirow{3}{*}{$\begin{array}{c}\text { Mixing water } \\
\text { pond }\end{array}$} & $\begin{array}{l}\text { Gut and } \\
\text { gill }\end{array}$ & $\begin{array}{l}2.22 \pm 3.768 \\
\text { particles/fish }\end{array}$ \\
\cline { 2 - 3 } & & $\begin{array}{l}1.111 \pm 1.167 \\
\text { particles/fish }\end{array}$ \\
\hline
\end{tabular}

Based on the characterization of microplastic, the most shape, color and size from both of gut, gill and tissue from milkfish samples in seawater ponds were blue fragments with size range $1000-5000 \mu \mathrm{m}$ and black fragments with sizes range $500-1000 \mu \mathrm{m}$. The most of shape, color abd size from both of gut, gill and tissue samples of milkfish were black fragments with saize range $500-1000 \mu \mathrm{m}$ and black fragments with size range 1000 - $5000 \mu \mathrm{m}$. The data are shown in Fig 5.

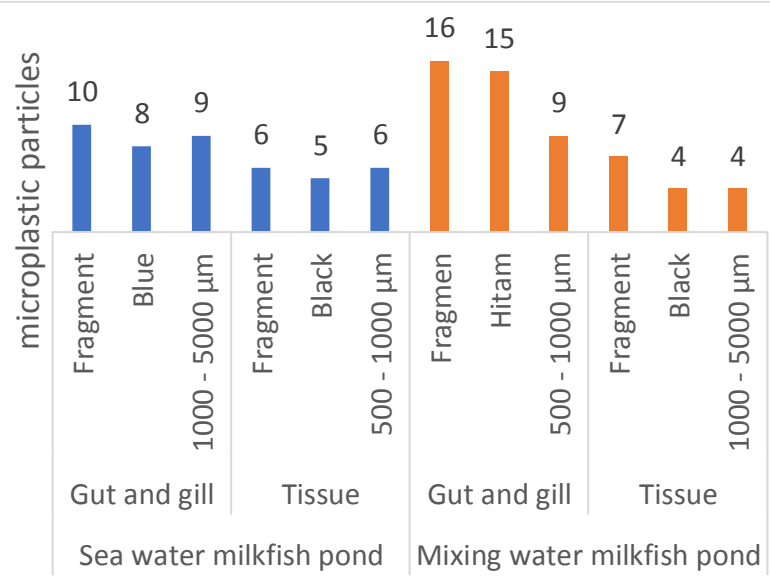

Fig 5. The amount of microplastic concentration based on shape, color and the size at milkfish samples

\subsection{Microplastic visualization by microscope}

Based on water, sediment, and milkfish samples observations, the fragment was found more often $90 \%$ in water, and milkfish samples and fibers were found $48 \%$ in sediment samples. The result of microplastic's shape shown in Fig 6.
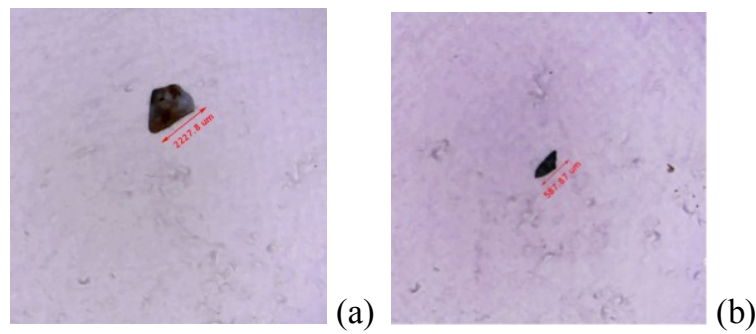

Fig 6. The microplastic shape on the microscope;(a) and (b) Fade Black fragment

\section{Conclusion}

The average of microplastic concentrations in Citarum River downstream for water and sediment samples were $0.0574 \pm 0.025$ particles $/ \mathrm{m}^{3}$ and $3.666 \pm 0.577$ particles/20gr. The average of microplastic concentration in water both of milkfish pond were 3,000 $\pm 2,645$ particles/L for seawater ponds and 0,666 $\pm 0,577$ particles/L for mixed water ponds, while the average of microplastic concentration in sediment at both of milkfish were $2,667 \pm 1,527$ particles/20gr for seawater 
pond and $2.333 \pm 0.577$ particles/20gr for mixed water pond. The average of microplastic concentration in gut and gill samples in milkfish from both of the ponds were $2.333 \pm 2.266$ particles/fish for seawater pond and $2.22 \pm$ 3.768 particles/fish for mixed water pond, while for microplastic concentrations in milkfish's tissue were $1,333 \pm 1,000$ particles/fish for milkfish from seawater pond and $1,111 \pm 1,167$ particles/fish for milkfish from mixed water pond.

\section{ACKNOWLEDGMENT}

This Research is funded by P3MI ITB 2019 and Asia Pacific Network (APN).

\section{References}

1. M.S. Tankovic, V.S Perusco, J. Godrijan, D.M Pfannkuchen. Marine plastic, (2015).

2. C. Ioakeimidis, C. Zeri, H. Kaberi, M. Galatchi, K. Antoniadis, N. Streftaris, F. Galgani, V. Papathanassiou, G.A. Papatheodorou. Comparative study of marine litter on the seafloor of coastal areas in the Eastern Mediterranean and Black Seas. Mar. Pollut. Bull, 89, 296-304 (2014).

3. M. Cole, P. Lindeque, C. Halsband and T. S. Galloway. Microplastics as contaminants in the marine environment. Mar.Pollut. Bull, 62(12), 25882597. (2011).

4. UNEP, Marine Plastic Debris and Microplastic Technical Report, United Nations Environmental Programme, Nairobi, (2016).

5. A. Lusher, in Marine Anthropogenic Litter, ed. M. Bergmann, L. Gutow and M. Klages, Springer, Berlin, ch. 10, pp.245-308. (2015).

6. M. Wagner, C. Scherer, D. Alvarez-Mũnoz, N. Brennholt, X. Bourrain, S. Buchinger, E. Fries, C. Grosbois, J. Klasmeier, T. Marti, S. RodriguezMozaz, R. Urbatazka, D. Vertaak, M. WintherNielsen and G. Reifferscheid. Microplastics in freshwater ecosystems: what we know and what we need to know. Environ. Sci. Eur, 26(12), 1-9. (2014)

7. D. Eerkes-Medrano, R. C. Thompson and D. C. Aldridge. Microplastics in fresh water systems: a review of the emerging threats, identification of knowledge gaps and prioritisation of research needs. Water Res, 75, 63-82. (2015).

8. K. Duis and A. Coors. Microplastics in the aquatic and terrestrial environment: sources (with a specific focus on personal care products), fate and effects. Environ. Sci. Eur, 28(1), 1-25. (2016).

9. K.-W. Lee, W. J. Shim, O. Y. Kwon and J.-H. Kang. Size-depenent effect of micro polysterene particles in marine copepod Tigriopus japonicus. Environ. Sci. Technol, 47(19), 11278-11283. (2013).

10. O. Set"al"a, V. Flemming-Lehtinen and $M$. Lehtiniemi. Ingestion and transfer of microplastics in the planktonic food web. Environ. Pollut., 185, 77-83. (2014).

11. E. Besseling, A. Wegner, E. M. Foekema, M. J. Van Den Heuvel-Greve and A. A. Koelmans. Effect of microplastic on fitness and PCB bioaccumulation by the lugworm Arenicola marina (L.). Environ. Sci. Technol, 47(1), 593-600. (2013).

12. D. S. Green, B. Boots, J. Sigwart, S. Jiang and C. Rocha. Effect of conventional and biodegradable microplastics on a marine ecsystems engineer (Arenicola marina) and sediment nutrient cycling. Environ. Pollut, 208, 426-434. (2016).

13. N. M. Hall, K. L. E. Berry, L. Rintoul and M. O. Hoogenboom. Microplastic ingestion by scleractinian corals. Mar. Biol, 162(3), 725-732. (2015).

14. K. L. Kaposi, B. Mos, B. P. Kelaher and S. A. Dworjanyn. Ingestion of microplastic has limited impact on a marine larva. Environ. Sci. Technol, 48(3), 1638-1645. (2014).

15. R. Sussarellu, M. Suquet, Y. Thomas, C. Lambert,C. Fabioux, M. E. J. Pernet, N. Le Gö1c, V. Quillien, C. Mingant, Y. Epelboin and C. Corporeau. Oyster reproduction is affected by exposure by exposure to polystyrene microplastics. Proc. Natl. Acad. Sci. U. S. A, 113(9), 2430-2435. (2016).

16. G. Vandermeersch, L. Van Cauwenberghe, C. R. Janssen, A. Marques, K. Granby, G. Fait, M. J. Kotterman, J. Diog`ene, K. Bekaert, J. Robbens and L. Devriese. View on microplastics quantification in aquatic organisms. Environ. Res, 143, 46-55. (2015).

17. C. M. Rochman, A. Tahir, S. L. Williams, D. V. Baxa, R. Lam, J. T. Miller, F. C. Teh, S. Werorilangi and S. J. Teh. Anthropogenic debris in seafood: plastic debris and fibers from textiles in fish bivalves sold for human consumption. Sci. Rep, 5, 14340, DOI: 10.1038/srep14340. (2015).

18. C. Ped'a, L. Caccamo, M. C. Fossi, F. Gai, F. Andaloro, L. Genovese, A. Perdichizzi, T. Romeo and G. Maricchiolo. Intestinal alteration in Eropa sea bass, Dicentratchus Labrax (Linnaeus, 1758) exposed to microplastics: preliminary result. Environ. Pollut, 212, 251-256. (2016).

19. C. D. Rummel, M. G. L"oder, N. F. Fricke, T. Lang, E. M. Griebeler, M. Janke and G. Gerdts. Plastic ingestion by pelagic and demersal fish from the North sea and Baltic Sea . Mar. Pollut. Bull, 102, 134-141. (2016).

20. P. S. Tourinho, J. A. I. do Sul and G. Fillmann. Is marine debris ingestion still a problem for the coastal marine biota of Southern Brazil? Mar. Pollut. Bull, 60(3), 396-401. (2010).

21. J. A. Van Franeker, C. Blaize, J. Danielsen, K. Fairclough, J. Gollan, N. Guse, P. L. Hansen, M. Heubeck, J. K. Jensen, G. Le Guillou and B. Olsen. Monitoring plastic ingestion by the nothern fulmar Fulmarus glacialis in the North Sea. Environ. Pollut, 159(10), 2609-2615. (2011).

22. Oliveira, M., Ribeiro, A., Hylland, K., Guilhermino, L. Single and combined effects of microplastics and pyrene on juveniles $(\mathrm{O}+$ group) of the common goby Pomatoschistus microps (Teleostei, Gobiidae. Ecol. Indic. 34, 641-647. (2013).

23. Cavelle, J. A Political Ecology of the Citarum River Basin: Exploring "Integrated Water Resources Management" in West Java, Indonesia, thesis, UC Berkeley. (2013).

24. Desforges JPW, Galbraith M, Dangerfield N, Ross PS. Widespread distribution of microplastic in 
subsurface seawater in the NE Pacific Ocean. Mar. Pollut. Bull. 71 (1): 94-99. (2014)

25. Dris, R. Johnny, G. Vincent, R. Mohamed, S. Nicolas, R. Bruno, T. Microplastic contamination in an urban area: a case study in Greater Paris. Environmental Chemistry DOI: 10.1071/EN14167. (2015)

26. Eriksen, M. Max, L. Tim, K. Louis, C. Abigail, A. Laurent, L. Heather, R. Barent, R. Nicolas, C. O. Valeria, H. R. Erika, M. Carolynn, B. Anna, C. Martin, T. Microplastic sampling with AVANI trawl compared to two neuston trawls in the Bay of Bengal and South Pacific. Environmental pollution 1-10. (2017)

27. Su, L., Hua, D., Bowei, L., Qiqing, C., Vincent, P., Chenxi, W., Huahong, S. The occurance of microplastics in specific organs in commercial caught fishes from coast and estuary area of east china. Journal of Hazardous Materials 365. 716-724. (2019)

28. Jantz LA, Morishige CL, Bruland GL, Lepczyk CA. Ingestion of plastic marine debris by longnose lancetfish (Alepisaurus ferox) in the North Pacific Ocean. Marine Pollution Bulletin 69:97-104 DOI 10. 1016/j.marpolbul..01.019. (2013).

29. F. C. Alam, S. Emenda, B. S. Muntalif, Suendo. V. 2019. Microplastic distribution in surface water and sediment river around slum and industrial area (case study : Ciwalengke river, Majalaya district. Indonesia). Chemosphere, 224, 637-645. (2019).

30. I. Atsuhiko, I. Shinsuke, U. Keiichi and T. Tadashi. Abundance of non-conservative microplastics in the upper ocean from 1957 to 2066 . Nature communications, 417, 2019. 